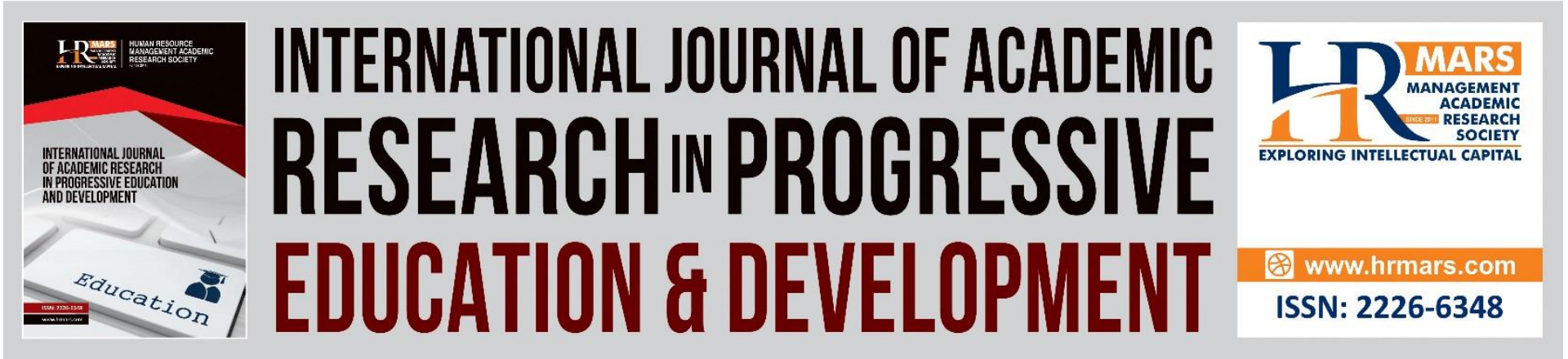

\title{
The Challenges of Home-Based Learning in COVID-19 Season: An Overview of Rural School in Sabah, Malaysia
}

Gurumoorthy Poobalan, Junaidi Asman, Roslee Talip, Rosna Padan, Zulhairul Ramlee, Sukuneswari Kaliappan

To Link this Article: http://dx.doi.org/10.6007/IJARPED/v10-i3/11367

DOI:10.6007/IJARPED/v10-i3/11367

Received: 07 July 2021, Revised: 13 August 2021, Accepted: 10 September 2021

Published Online: 30 September 2021

In-Text Citation: (Poobalan et al., 2021)

To Cite this Article: Poobalan, G., Asman, J., Talip, R., Padan, R., Ramlee, Z., \& Kaliappan, S. (2021). The Challenges of Home-Based Learning in COVID-19 Season: An Overview of Rural School in Sabah, Malaysia. International Journal of Academic Research in Progressive Education and Development, 10(3), 1043-1051.

Copyright: (C) 2021 The Author(s)

Published by Human Resource Management Academic Research Society (www.hrmars.com)

This article is published under the Creative Commons Attribution (CC BY 4.0) license. Anyone may reproduce, distribute, translate and create derivative works of this article (for both commercial and non-commercial purposes), subject to full attribution to the original publication and authors. The full terms of this license may be seen

at: http://creativecommons.org/licences/by/4.0/legalcode

Vol. 10(3) 2021, Pg. 1043 - 1051

http://hrmars.com/index.php/pages/detail/IJARPED

JOURNAL HOMEPAGE

Full Terms \& Conditions of access and use can be found at http://hrmars.com/index.php/pages/detail/publication-ethics 


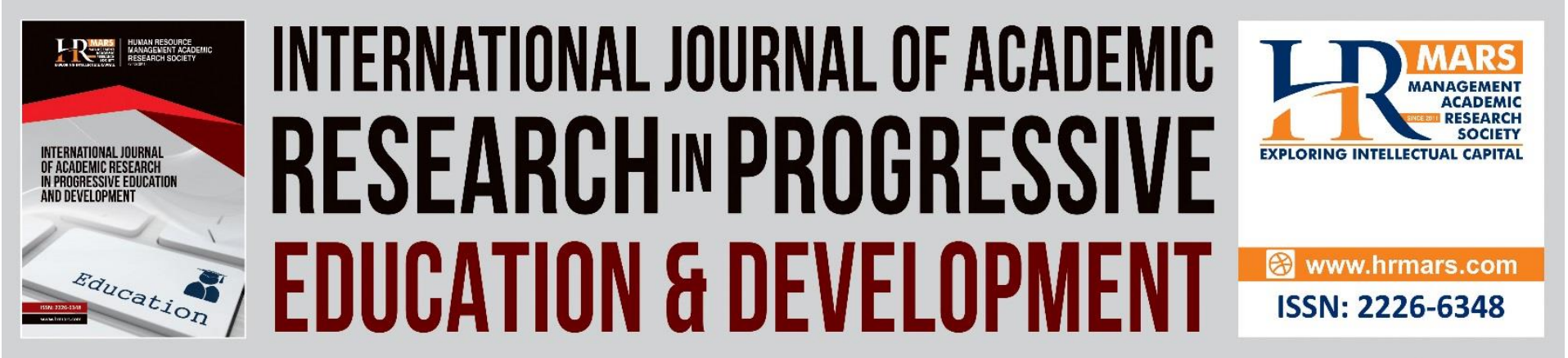

\title{
The Challenges of Home-Based Learning in COVID-19 Season: An Overview of Rural School in Sabah, Malaysia
}

\author{
Gurumoorthy Poobalan \\ Faculty of Psychology and Education, University Malaysia Sabah, 88400 Kota Kinabalu, \\ Sabah, Malaysia \\ Email: guru8826@gmail.com \\ Junaidi Asman \\ D/A Pejabat Pelajaran Daerah Kecil Lawas, 98850, Lawas, Sarawak, Malaysia \\ Email: junaidiasmanskll@gmail.com \\ Roslee Talip
}

Faculty of Psychology and Education, University Malaysia Sabah,88400 Kota Kinabalu,

Sabah, Malaysia

Email: roslee_73@ums.edu.my

Rosna Padan

D/A Pejabat Pelajaran Daerah Kecil Lawas, 98850, Lawas, Sarawak, Malaysia

Email: rosnapadan@yahoo.com

Zulhairul Ramlee

SMK Beluran Peti Surat 30, 90107 Beluran, Sabah, Malaysia

Email: sirharoldlee@yahoo.com

Sukuneswari Kaliappan

SMK Balaban Jaya Peti Surat 108, 90108 Beluran, Sabah, Malaysia

Email: Krismaithili@yahoo.com

\begin{abstract}
The COVID-19 epidemic has spread throughout the country, affecting nearly every area, including the education sector. Since the adoption of the Movement Control Order (MCO) on March 18, 2020, home-based learning has been widely implemented across the country for quite some time. The purpose of this study is to assess the problems that students faced while learning at home during the COVID-19 academic season. This research was carried out at a rural school in the Sabah district of Beluran. Pupils in Forms 4 and 5 (a total of 178 students)
\end{abstract}


were involved in this study. The survey was carried out through the use of a Google form, which was sent to students through social media. According to the findings of the survey, students experience a total of 18 challenges when it comes to completing their homework and performing their homework assignments at home. The students themselves have also contributed some tips for tackling the difficulties associated with home-based learning. We expect that the findings of this study will serve as a guide for teachers, schools, district education office management, the State Education Department, and the Ministry of Education Malaysia in developing policies and coordinating the implementation of homebased learning programs in the future.

Keywords: Challenges, Suggestion, Home based Learning, Covid-19.

\section{Introduction}

The emergence of the Covid-19 virus in Malaysia since early 2020 has had a significant impact on numerous sectors and populations. Since early 2020, the economic slump and job losses, as well as a lack of income, have had an influence on people's well-being (Aneja \& Ahuja, 2021, Lu, et. al., 2021; Trisnowati \& Muditomo, 2021). Furthermore, student education is beginning to encounter a number of obstacles. Educators were then exposed to home-based learning systems (Yansen et. al., 2021; Suzanna et. al., 2020)

Home-based learning (HBL) did not have a stable framework that could allow teachers and students communicate in order to hold home-based learning online initially. Teachers encountered numerous obstacles at the time in bridging the technology gap, particularly in the adoption of home-based learning. However, after completing numerous rounds of Movement Control Command (MCO), teachers can bridge the digital divide in home-based learning thanks to the availability of Google Classroom, Google Meet, Microsoft Teams, and various HBL programs.

The role of teachers and students in the implementation of home-based learning is critical to achieving student growth. Students are meant to learn when teachers teach. This is not the case in the case of home-based learning. Students who do not attend home-based learning sessions online cannot be controlled, forced, or fined by teachers. This is due to the fact that educators must consider the demographics of students, their economic condition, and their psychology when it comes to participation in home-based learning classes.

As a result, the absence of students from home-based learning or a lack of HBL work is a problem that teachers should investigate when planning student activities. As a result, researchers undertook this survey study to learn about the obstacles of home-based learning from the perspective of students and to provide solutions.

\section{Study Objectives}

The following are the study's objectives:

a) Identify the challenges of home-based learning from the standpoint of students.

b) Identify solutions for overcoming the problems of home-based learning from the students' perspective. 


\section{Literature Review}

Due to the extreme COVID-19 pandemic, schools have been forced to close, transferring teaching and learning to full-time home learning (HBL). Technology is vital, but developing an online learning environment that engages students meaningfully is a complicated task. Online learning is not a new instructional method in the educational environment, thanks to the incorporation of technology in teaching and learning. The advent of the Covid-19 epidemic, on the other hand, has required the introduction of Home-Based Learning (HBL) for educators, parents, and children on an unprecedented timeline and scale. The significance of $\mathrm{HBL}$ and the elements influencing its implementation have not been thoroughly examined.

Previous research has found that it is more important to develop an adaptive gamification system to engage diverse students with diverse needs, to provide professional support and development for school teachers to increase student engagement in pdpr (Wen et al., 2021), and to involve students in the context of online learning. We must reject the notion that there is a single software application for all learning activities; online social networking platforms may be required for student discussion in home-based learning classes; and students must be instilled with more focused skills and habits for online learning and face-to-face contexts (Tay et. al., 2021).

This type of home-based learning can help students develop their self-learning abilities. Teachers and parents, on the other hand, must nurture and equip children with the skills required to become oriented learners for student well-being (Wai, 2020). Furthermore, teachers' high preparedness in identifying and designing interventions to assist students in implementing home-based learning is critical for successful home-based teaching and learning (Mansor et. al., 2021).

Furthermore, a shortage of textbooks and instructions to promote home learning hinder the effectiveness of efforts to ensure continuity of home-based learning (Chabbott \& Sinclair 2020). Additionally, parents serve as stimulants and educators for their children at home, assisting them in implementing home-based learning. Thus, the cooperation of parents and instructors, as well as parents' educational level, particularly skills in the application of technology at home, influence the success of home-based learning (Triutami, \& Muljani, 2021; Lestari \& Prima, 2021).

According to Liu et al (2021), there are four strategies provided to increase the effectiveness of home-based learning, which are to stimulate students' sense of learning, to nurture students' self-management ability, to give each student the opportunity to better reflect the characteristics of diversity in the process of participation, and finally to benefit intelligence in the online classroom. Moreover, feedback and reflection, teacher assistance, and defined objectives in the implementation of home-based learning can boost students' pleasure and self-confidence (Tan et.al., 2021).

However, proper teacher planning in terms of teaching tools and oral instruction via online platforms can help develop English communication abilities (Maria et.al., 2021). Further, in the implementation of experimental home based learning, parents play a crucial role as collaborators with teachers and children in order to ensure student safety, monitor their 
DEVELOPMENT

Vol. 10, No. 3, 2021, E-ISSN: 2226-6348 @ 2021 HRMARS

child's progress, provide a safe environment, and conducive study environments (Robledo, 2021).

\section{Methodology}

The purpose of this research is to look at the problems of home-based learning from the perspective of students. This research is more quantitative as well as descriptive. Survey methods are used to identify pupils' home-based learning challenges. This research was carried out in a school in a remote part of Sabah. The sample for this study consisted of 178 children from grades 4 and 5. To obtain data, a questionnaire instrument in the form of a Google form was developed. As collect data, the generated questionnaires were distributed to certain social media groups. The students are chosen based on their engagement among the less active home-based learning classes and the researcher's own experience as the subject teacher for the class.

This questionnaire comprises only two items that students must complete: home-based learning challenges and methods to overcoming them from the students' perspective. Each respondent was also awarded an e-certificate via the attachment. The gathered data were analyzed using Microsoft Excel software and interpreted in the form of simple graphics.

\section{Findings}

According to the study's findings, there are 18 different types of challenges that students confront when implementing home-based learning. Graph 4.1 depicts the outcomes of 18 different types of home-based learning challenges.

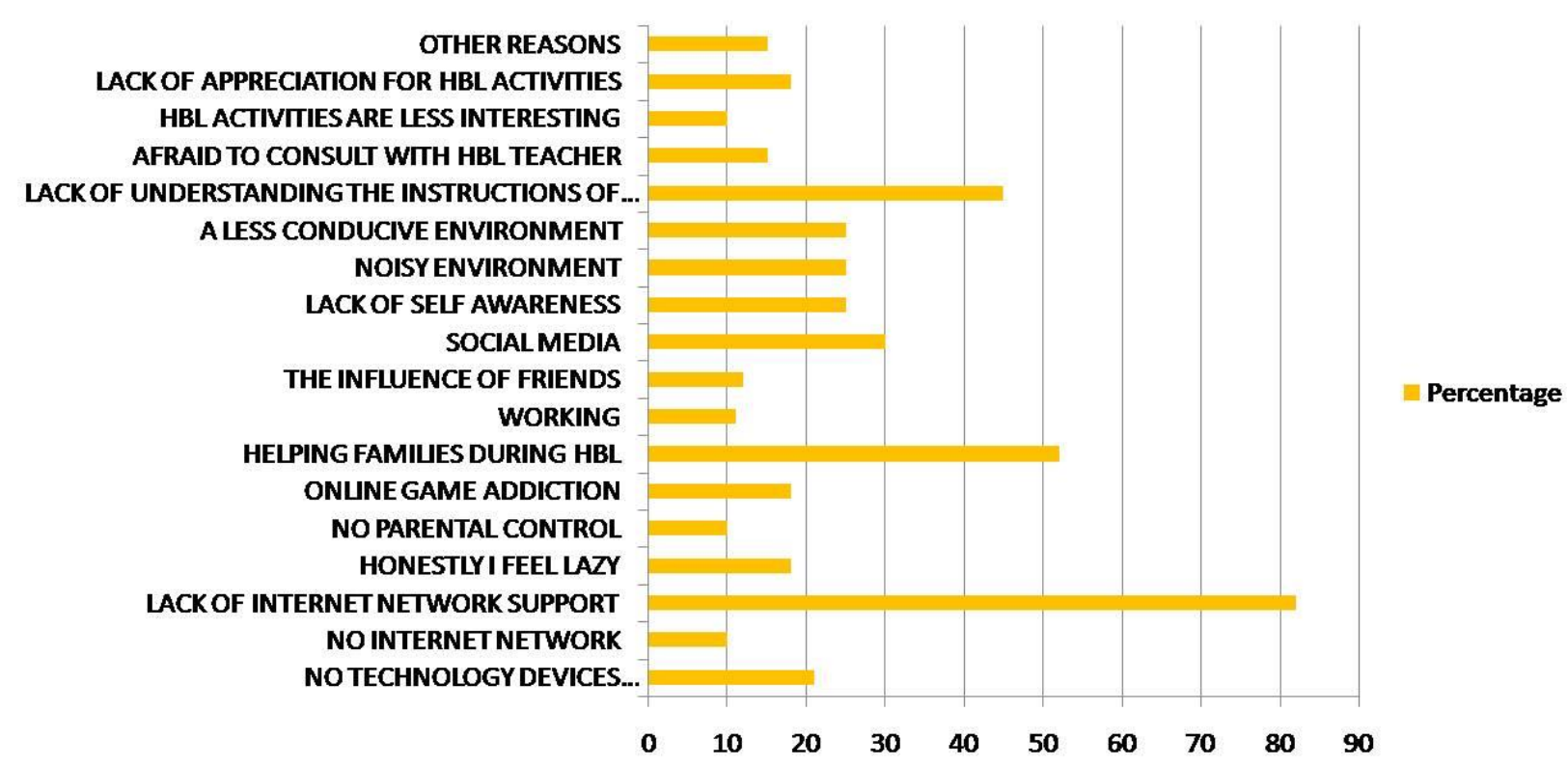

Figure 4.1 Percentage graph of home base learning (HBL) challenges

According to Figure 4.1, there are three major challenges faced by students in the implementation of home base learning, namely a lack of internet network support with an 82 percent student voting frequency, assisting families during home base learning with a 52 percent student voting frequency, and finally a lack of understanding of the instructions of 
DEVELOPMENT

Vol. 10, No. 3, 2021, E-ISSN: 2226-6348 @ 2021 HRMARS

each home base learning class. It is obvious that rural areas have an inadequate internet network.

Following that, there are five medium-level home base learning challenges, namely the influence of social media with a percentage of student voting frequency of $30 \%$, a lack of selfawareness with a percentage of student voting frequency of $25 \%$, and a noisy environment with a percentage of student voting frequency of $25 \%$, a less conducive environment with a 25 percent student voting frequency, and ultimately no technological gadgets (smartphones, laptops, printers) with a 21 percent student voting frequency.

The data also reveal him 7 more challenges that are at a moderately low level in terms of his voting \% frequency. Among the seven challenges are honestly I feel lazy, online game addiction, and a lack of appreciation for home base learning activities that have the same percentage of student voting frequency of 18 percent, being afraid to consult with home base learning teachers, and other reasons (stress, storage devices exceeding the limit, and HBL teachers' indifference) which have the same percentage of student voting frequency of 18 percent.

Furthermore, there are three problems of home base learning from the perspective of students with a low percentage frequency: no network, no parental control, and ultimately less appealing HBL activities with the same percentage of student voting frequency of $10 \%$. Finally, these 18 problems have an impact on students when it comes to implementing homebased learning. This issue of home-based learning must be overcome and addressed so that teachers can help students reach their full potential.

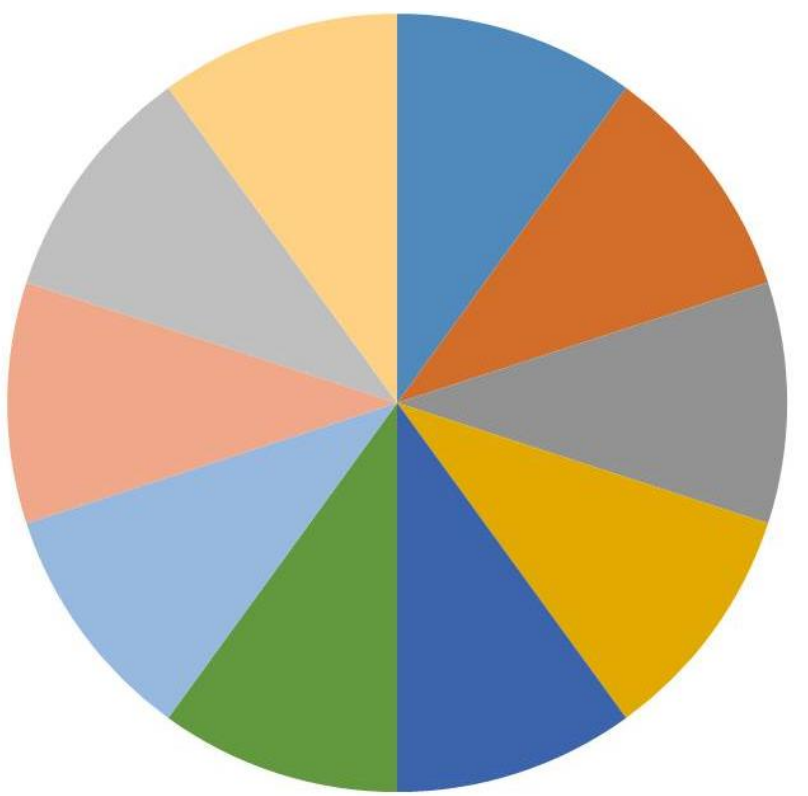

\author{
- PERSONALSCHEDULE \\ - HBL GIFTS \\ - MOTIVATION \\ I SHORT \& COMPACT HBL \\ INSTRUCTIONS \\ - BE BRAVE \\ — INTENT \& EFFORT \\ DEVICE BORROWING \\ OPTIONS \\ GOOGLEMEET/FACE TO \\ FACE \\ ENVIRONMENT \\ MULTIPLE INTERNET \\ SUBSTATIONS
}

Figure 4.2 Suggestion to overcome challenges of home based learning from a Student's Perspective

According to figure 4.2, there are ten ideas made by students themselves for addressing the challenges associated with home-based learning that they have experienced. Create a personal schedule, enquire for a gift for participation in home-based learning, seek motivation from teachers, expect home-based learning instructions to be simple, concise and clear, try 
to be brave enough to refer teachers if they do not understand home-based learning classes, always intend and strive, students searching for an option to look for devices such as smart phones, students also desire Google Meet or any other tool that allows teachers and students to interact face to face in home based learning. Students should also discover and plan an appropriate home environment for home-based learning. Finally, students requested expanding the number of substations that connect to the internet network in residential areas. All of these solutions represent thoughtful suggestions from students themselves for overcoming the obstacles or challenges of home-based learning, and they should be adopted as a model by educational authorities in order to combat the problem of student dropout in home-based learning.

\section{Discussion and Implications}

The purpose of this research is to uncover the challenges of home-based learning and how to overcome them from the perspective of students themselves. According to the findings of the study, the challenges of home-based learning from the perspective of students may be classified into nine major categories: the internet, students' self-awareness, the environment, social media, family burden, peer influence, self-motivation, teachers, and parents. The internet is crucial in delivering home-based learning sessions. These constraints, however, can be circumvented through module, project, and problem-based learning. This can be accomplished through educational institution collaboration and educators' commitment to generating and sharing modules for the implementation of home-based learning.

Students' self-awareness explains why they are less conscious of the relevance of home-based learning and its relationship to the future, as well as their own preparation to face homebased learning classes. Teachers of home-based learning disciplines must play a role in connecting learning across the curriculum to the actual world so that students become aware of the importance of learning.

While the environment comprises a pleasant learning environment that is appropriate for students' needs, it is also a source of dropouts in home-based learning. Parents should assist their children in providing a conducive and uninterrupted learning environment so that pupils can focus and adhere to home-based learning.

Next, social media influences students' attitudes, making them too lethargic to attend homebased learning sessions. Due to a lack of parental control or the constraints of self-learning, students may become addicted to online games, facebook, instagram, or even visit websites that include pornography via social media. As a result, parents or family members should always supervise their children's movements, especially when they are using the internet.

One of the reasons students drop out of home-based learning sessions is because of family obligations. In this Covid -19 season, parents are likely to lose their employment or experience a loss of money, forcing students' as a children to find work in order to support their families and make a living. The school or teachers must identify the pupils who are participating in the employment, assist them, and encourage them to take home-based learning classes.

Furthermore, the influence of peers is a cause why kids do not engage in home-based learning. A good friend can effect change, whereas a friend who lacks excellent manners will drive other friends to abandon home-based learning. Furthermore, student motivation influences students' willingness to pursue home-based learning. Teachers assist students with motivational stimuli in home-based learning classes. As a result, in home-based learning, 
teachers should always stimulate pupils by offering compliments, praise, and presents such as certificates, reference books, and smartphone topup (reload) money.

In addition, teachers play an important role in home-based learning. Each lesson in a homebased learning program should be simplified and reduced so that students may readily understand it. Teachers should also collect student feedback for each home-based learning assignment. Student responses can influence both students' and teachers' teaching techniques. Parents should also supply home-based learning equipment and collaborate with teachers so that their children's learning is more successful. They should also aid each other in the success of home-based learning classes and, in turn, form the backbone of student growth.

The implication is that students' commitment in pursuing home-based learning should be recognized and rewarded on a regular basis by teachers. Teachers should be motivators for their pupils, both through virtual home-based learning classes and face-to-face modules. The school, particularly the teachers, should apply face-to-face home-based learning online or on a regular basis based on the findings in the provision of face-to-face modules. Students will be more motivated to pursue home-based learning as a result of this. Students are the future nation's cornerstones. Teachers should therefore improve the effectiveness of self-learning through home-based learning sessions. Based on the findings, the Malaysian Ministry of Education should provide guidelines for parents, teachers, and students to ensure the success of home-based learning classes.

\section{Conclusion}

This study has the potential to open the minds of all stakeholders in assessing the challenges of home-based learning from the perspective of students, as well as strategies to overcome them. The participation of all parties in the implementation of home-based learning can assist build and support student results and prevent student dropouts. As a result, this study can and should serve as a guide by bridging the gap between policymakers and implementers, namely teachers who are also facilitators who work hard to ensure the success of policies and policies aimed at building and enhancing student development even during the Covid-19 pandemic.

\section{References}

Aneja, R., \& Ahuja, V. (2021). An Assessment of Socioeconomic Impact Of COVID-19 Pandemic in India. Journal of Public Affairs, 21(2). Https://Doi.Org/10.1002/Pa.2266

Chabbott, C., \& Sinclair, M. (2020). SDG 4 And The COVID-19 Emergency: Textbooks, Tutoring, And Teachers. Prospects, 49(1-2), 51-57. Https://Doi.Org/10.1007/S11125-020-09485$Y$

Mansor, A. N., Zabarani, N. H., Jamaludin, K. A., Nor, M. Y. M., Alias, B. S., \& Mansor, A. Z. (2021). Home-Based Learning (Hbl) Teacher Readiness Scale: Instrument Development and Demographic Analysis. Sustainability (Switzerland), 13(4), 1-15. Https://Doi.Org/10.3390/Su13042228

Lestari, P. I., \& Prima, E. (2021). Home-Based Learning Di Masa Normal Baru: Partisipasi Orang Tua Anak Usia Prasekolah. Jurnal Obsesi : Jurnal Pendidikan Anak Usia Dini, 6(1), 208219. Https://Doi.Org/10.31004/Obsesi.V6i1.1215 
Liu, H. H., Ye, Y. C., \& Jiang, H. L. (2021). Self-Efficacy in Home-Based Online Learning Environments. Journal of Internet Technology, 22(3), 557-567. Https://Doi.Org/10.3966/160792642021052203006

Lu, L., Peng, J., Wu, J., \& Lu, Y. (2021). Perceived Impact of The Covid-19 Crisis on Smes In Different Industry Sectors: Evidence from Sichuan, China. International Journal of Disaster Risk Reduction, 55. Https://Doi.Org/10.1016/J.ljdrr.2021.102085

Maria, C. R. I. (2021). Using Communicative Approach in Teaching Speaking Competence of Young Learners Through Home-Based Learning. Kne Social Sciences. Https://Doi.Org/10.18502/Kss.V5i3.8535

Robledo, D. A. (2021). Biology at Home: The Six Attributes of Home-Based Biology Experiments (Hbes) For Remote Authentic Learning. Psychology and Education, 58(3), 4319-43123. Retrieved From Http://Psychologyandeducation.Net/Pae/Index.Php/Pae/Article/View/48 58

Suzanna, S., Sasmoko, S., Lumban Gaol, F., Oktavia, T., \& Matsuo, T. (2020). Exploration of Technology Home-Based Learning Guidance for Parents and Students During the Covid19 Pandemic. In Proceedings - 2020 9th International Congress on Advanced Applied Informatics, IIAI-AAI 2020 (Pp. 122-127). Institute of Electrical and Electronics Engineers Inc. Https://Doi.Org/10.1109/IIAI-AAI50415.2020.00033

Tan, S. H. X., Ansari, A., Ali, N. M. I., \& Yap, A. U. (2021). Simulation Design and Students' Satisfaction with Home-Based Simulation Learning in Oral Health Therapy. Journal of Dental Education, 85(6), 847-855. Https://Doi.Org/10.1002/Jdd.12576

Tay, L. Y., Lee, S. S., \& Ramachandran, K. (2021). Implementation of Online Home-Based Learning and Students' Engagement During The COVID-19 Pandemic: A Case Study Of Singapore Mathematics Teachers. Asia-Pacific Education Researcher, 30(3), 299-310. Https://Doi.Org/10.1007/S40299-021-00572-Y

Trisnowati, Y., \& Muditomo, A. (2021). COVID-19 And Stock Market Reaction in Indonesia. Journal of Accounting and Investment, 22(1), 23-36. Https://Doi.Org/10.18196/Jai.V22i1.8859

Triutami, C. S., \& Muljani, R. (2021). Exploring Parents' Home-Based Involvement in Their Children's English Learning: Triggers and Barriers. Project (Professional Journal of English Education), 4(1), 35. Https://Doi.Org/10.22460/Project.V4i1.P35-46

Wai-Cook, M. S. S. (2020). The Reality of Home-Based Learning During COVID-19: Roles of Parents, Teachers, And School Administration in Promoting Self-Directed Learning. Journal of School Administration Research and Development, 5(S2), 86-92.

Wen, Y., Gwendoline, C. L. Q., \& Lau, S. Y. (2021). ICT-Supported Home-Based Learning In K12: A Systematic Review of Research and Implementation. Techtrends, 65(3), 371-378. Https://Doi.Org/10.1007/S11528-020-00570-9

Yansen, Komariah, A., \& Satori, D. (2021). Character Education in Home Based Learning During COVID-19 Pandemic. In Proceedings of the 4th International Conference on Research of Educational Administration and Management (ICREAM 2020) (Vol. 526). Atlantis Press. Https://Doi.Org/10.2991/Assehr.K.210212.037 